\title{
Studying Air Pollutants Origin and Associated Meteorological Parameters over Seoul from 2000 to 2009
}

\author{
Sunmin Park, ${ }^{1}$ Hesham El-Askary, ${ }^{2,3,4}$ Ismail Sabbah, ${ }^{5,6}$ Hanbin Kwak, ${ }^{7}$ \\ Anup K. Prasad, ${ }^{8}$ Woo-Kyun Lee, ${ }^{7}$ and Menas Kafatos ${ }^{3}$ \\ ${ }^{1}$ Department of Earth Science, University of California Riverside, Riverside, CA 92521, USA \\ ${ }^{2}$ Schmid College of Science and Technology, Chapman University, Orange, CA 92866, USA \\ ${ }^{3}$ Center of Excellence in Earth Systems Modeling and Observation, Chapman University, Orange, CA 92866, USA \\ ${ }^{4}$ Department of Environmental Sciences, Faculty of Science, Alexandria University, Moharam Bek, Alexandria 21522, Egypt \\ ${ }^{5}$ Department of Natural Sciences, College of Health Sciences, Public Authority for Applied Education and Training, \\ Faiha, P.O. Box 14281, 72853 Kuwait, Kuwait \\ ${ }^{6}$ Department of Physics, Faculty of Science, Alexandria University, Moharam Bek, Alexandria 21522, Egypt \\ ${ }^{7}$ Department of Environmental Science \& Ecological Engineering, Korea University, Seoul 136-713, Republic of Korea \\ ${ }^{8}$ Department of Applied Geology, Indian School of Mines, Dhanbad 826004, India
}

Correspondence should be addressed to Woo-Kyun Lee; leewk@korea.ac.kr

Received 27 August 2014; Accepted 23 January 2015

Academic Editor: Slobodan Nickovic

Copyright (C) 2015 Sunmin Park et al. This is an open access article distributed under the Creative Commons Attribution License, which permits unrestricted use, distribution, and reproduction in any medium, provided the original work is properly cited.

We investigate the temporal characteristics of major air pollutants collected from 44 air quality stations over the city of Seoul, Korea, namely, nitrogen dioxide, carbon monoxide, particular matter at 10 microns, and sulfur dioxide $\left(\mathrm{SO}_{2}\right)$ between 2000 and 2009. The corresponding satellite datasets, namely, aerosol optical depth $\left(\mathrm{AOD}_{\text {sat }}\right)$, Ångström exponent, and fine mode fraction, collected from moderate resolution imaging spectroradiometer (MODIS) as well as the Aeronet ground aerosol optical depth $\left(\mathrm{AOD}_{\text {aeronet }}\right)$, have been analyzed. Pollutants' seasonal effect has been inferred from the precipitation and temperature. The four pollutants under study show varying temporal characteristics with different annual mean concentration patterns. The monthly mean of mentioned pollutants all show similar low concentrations during the summer season and high concentrations during the winter season. We found that pollution is strongly linked to temperature and precipitation variability, especially during the fall season. Satellite data analysis provides information on the pollutants origin whether of natural or anthropogenic type. Our results indicate that the anthropogenic aerosol is dominant in the summer season even though the concentration was lower than the other seasons. $\mathrm{AOD}_{\text {aeronet }}$ and Ångström exponent indicated high positive and negative correlation coefficients with $\mathrm{PM}_{10}, 0.60$, and -0.45 , respectively. Both small and large sizes of aerosols existed in 2007; however coarse size of aerosols was the primary component in 2002 .

\section{Introduction}

Over the last few decades we have witnessed a large increase in the amounts and types of pollutants that emitted into the atmosphere since the Industrial Revolution. Their direct and indirect influences have been of concern due to their significant harm to human health, crops, and vegetation on regional and local (microzone) scales [1-4]. Although aerosols impact the global climate via different physical processes, yet a stronger impact on regional scales is particularly expected [5].
However, the physical characteristics, spatial distribution, and dynamics of aerosols are not completely understood [6-9]. Ground-based data enable the climatology of the aerosol attributes to be observed $[10,11]$, which can be verified by the application of satellite data $[12,13]$. The origin of aerosols' effects and relationships with meteorological factors are essential elements in the study of mesoscale modeling, as well as regional impacts [14]. They can be of either natural origin such as dust storms, forest fires, and volcanoes or anthropogenic one such as electricity generation, traffic, 


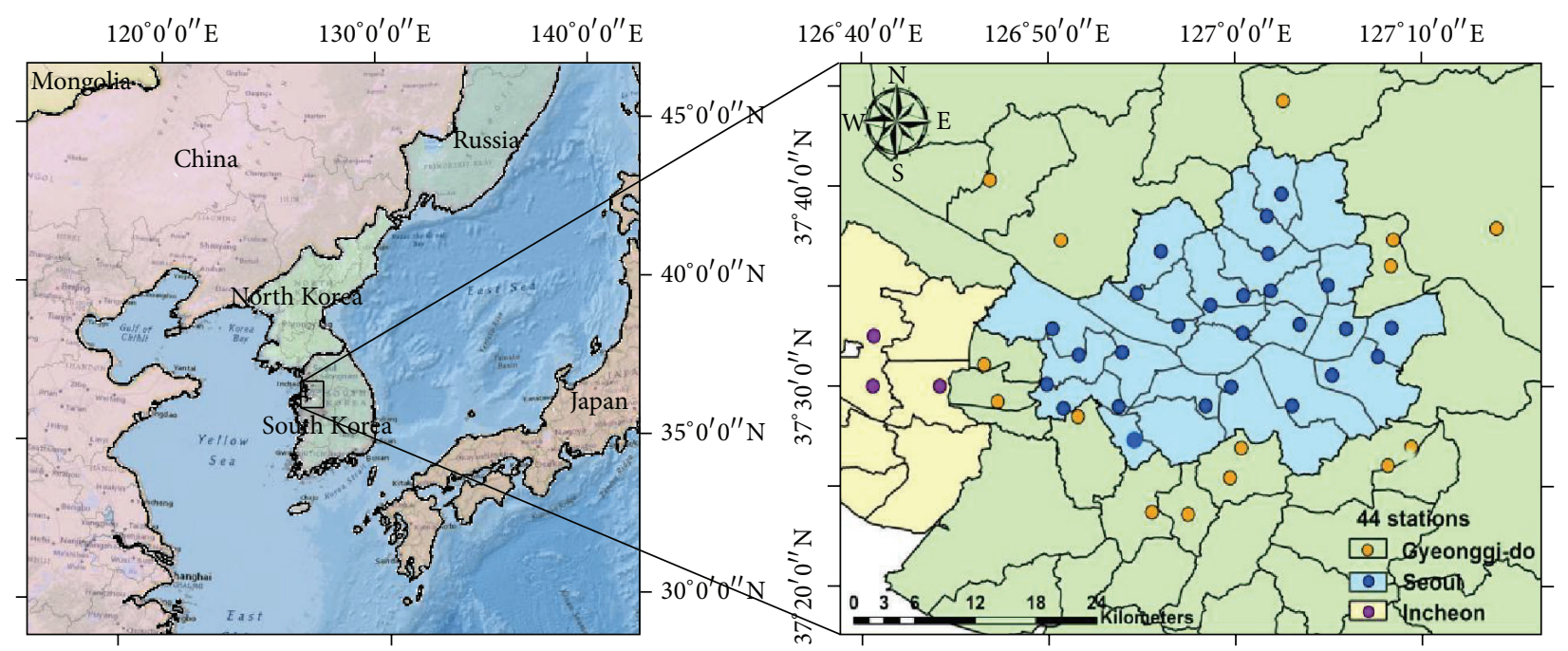

FIGURE 1: Base map of the study area, showing 44 air pollution monitoring stations.

wood fire heating, and industrial manufacturing processes [15-24].

East Asia has been experiencing frequent extremely high concentrations of sulfates, black carbon, nitrates, and organic matters due to increasing fossil fuel burning, as reported from the ACE-Asia campaign [25]. Previous work showed that the anthropogenic aerosols over the Eastern Asia were of much higher concentrations than those over Europe and the Eastern US [26, 27]. Kim et al. [28] investigated diurnal behavior and exceedance patterns of air quality criteria, ozone $\left(\mathrm{O}_{3}\right)$, and nitrogen dioxide $\left(\mathrm{NO}_{2}\right)$ in Seoul and showed that their behavior is strongly linked with geographical and meteorological factors. Harmful pollutants were observed at regional and temporal scales for particulate matter $\left(\mathrm{PM}_{10}\right)$ concentration over seven cities in Korea during the 2002 dust event as compared to the 2001 one [18].

Of particular concern is urban aerosol pollution, which has been the subject of many studies. Typical results of industrialization and urbanization have indicated many problems arising from urban aerosols [17, 29-33].

A great deal of research on aerosols has been carried out for several specific air pollutants in terms of their origin and relationship with meteorological parameters or seasonality using either ground or satellite observations [16, 34-38]. Using satellite observation data is an efficient way to determine and distinguish the optical properties of aerosols as it provides more complete coverage over longer time scales [32, 39-42]. Ground-based and satellite sensing of air pollutants may show different, but complementary characteristics; however, both are important in different situations, as well as for cross validation of the pollution origin [8].

Chang and Lee [34] investigated the temporal variation of air quality over Taipei city and found that primary pollutants such as carbon monoxide (CO), $\mathrm{NO}_{x}$, and sulfur dioxide $\left(\mathrm{SO}_{2}\right)$ showed low concentration from local source activities when wind speed increases and the temperature drops. However, dusty days in Kuwait contributed to an evident decrease in temperature [43]. Choi et al. [44] found a possible relationship between cloud formation and $\mathrm{PM}_{10}$ on weekly timescales when studying the interaction between $\mathrm{PM}_{10}$ and the meteorological parameters in the boundary layer over China. Lee et al. [45] found that the annual mean $\mathrm{SO}_{2}$ concentration in Seoul was higher than in Hamilton, Canada, and lower than in Chicago yet with the highest values during the winter season in Seoul, which is consistent with the high winter-time fuel usage.

The main purpose of the present work is to study the sources and origin of aerosol loading, being natural or anthropogenic, over Seoul, using ground and satellite observations between 2000 and 2009. We also investigate the relationships between pollutants, namely, $\mathrm{NO}_{2}, \mathrm{CO}, \mathrm{SO}_{2}$, and $\mathrm{PM}_{10}$, and meteorological parameters such as temperature, precipitation, and wind speed to determine the influence of meteorological conditions on pollutants concentrations.

\section{Materials}

2.1. Study Area. The study area is Seoul, the capital of South Korea, and its basin area, located in $126^{\circ} 62^{\prime} \mathrm{E}, 37^{\circ} 99^{\prime} \mathrm{N}$ and enclosed by mountains to the north and east (Figure 1). Seoul is characterized by noticeable distinction between the four seasons with warm weather in spring, hot and humid in summer, cool in fall, and cold and dry in winter [46].

Seoul has been experiencing serious pollution problems from local and external sources and in turns systemically polluting surrounding cities. In addition, it is one of the most densely populated cities in the world, with approximately $49 \%$ of Korea's entire population and $46 \%$ of vehicles holdings; however, it only occupies $12 \%$ of Korea's land area $\left(605.25 \mathrm{~km}^{2}\right)$. Most $\mathrm{NO}_{x}$ and $\mathrm{CO}$ are emitted from vehicles, while $\mathrm{SO}_{x}$ and $\mathrm{PM}_{10}$ are emitted from manufacturing related combustion [47, 48]. Moreover, dust storms from China [49] also regularly cause an increase in the $\mathrm{PM}_{10}$ concentration and threaten people's health with respiratory and cardiovascular diseases [50]. 
TABLE 1: The characteristics and source of data used in this study.

\begin{tabular}{|c|c|c|c|}
\hline Parameter & Time period & Frequency & Source \\
\hline $\mathrm{SO}_{2}$ & $2000-2009$ & Hourly & \multirow{5}{*}{$\begin{array}{l}\text { National Institute of } \\
\text { Environmental Research (NIER) }\end{array}$} \\
\hline $\mathrm{NO}_{2}$ & 2000-2009 & Hourly & \\
\hline $\mathrm{CO}$ & 2000-2009 & Hourly & \\
\hline $\mathrm{PM}_{10}$ & 2000-2009 & Hourly & \\
\hline Dust frequency & 2000-2009 & Monthly & \\
\hline Precipitation & $2000-2007$ & Daily & \multirow{2}{*}{$\begin{array}{l}\text { Automatic Weather System } \\
\text { (AWS) }\end{array}$} \\
\hline Temperature & $2000-2007$ & Daily & \\
\hline Relative humidity (RH) & 2000-2009 & Monthly & $\begin{array}{l}\text { Korea Meteorological } \\
\text { Administration (KMA) }\end{array}$ \\
\hline Wind speed & $2000-2007$ & Daily & $\begin{array}{l}\text { National Oceanic and } \\
\text { Atmospheric Administration } \\
\text { (NOAA) }\end{array}$ \\
\hline Fine mode fraction (FMF) & $2000-2009$ & Monthly & \multirow{3}{*}{$\begin{array}{l}\text { The Moderate Resolution } \\
\text { Imaging Spectroradiometer } \\
\text { (MODIS) Retrieval/Terra }\end{array}$} \\
\hline $\begin{array}{l}\text { Aerosol optical depth } \\
\left(\mathrm{AOD}_{\text {sat }}\right)\end{array}$ & 2000-2009 & Monthly & \\
\hline Ångström exponent & 2000-2009 & Monthly & \\
\hline $\begin{array}{l}\text { Aerosol optical thickness } \\
\left(\mathrm{AOD}_{\text {aeronet }}\right)\end{array}$ & 2000-2007 & Monthly & $\begin{array}{l}\text { Aerosol Robotic Network } \\
\text { (AERONET) }\end{array}$ \\
\hline
\end{tabular}

2.2. Data Sets. This work covers ten years period from 2000 to 2009 using ground and satellite observations to analyze the existing patterns and origin of pollutants over Seoul in relation to the prevailing meteorology [34]. Ground observation data, including $\mathrm{SO}_{2}, \mathrm{NO}_{2}, \mathrm{PM}_{10}$, and $\mathrm{CO}$, were measured at 44-air pollution monitoring stations, managed by the National Institute of Environmental Research (Figure 1). Twenty-six stations of which are situated within the Seoul metropolitan area while the other eighteen stations surrounding Seoul were used for correcting edge effects of air pollutants over Seoul. At these stations, the data for the four air pollutants were continuously measured during the study period (Table 1).

Temperature and precipitation have been provided from 46 Automatic Weather Systems (AWS) located in the same boundary areas as air pollutants, by the Korea Meteorological Administration (KMA), between 2000 and 2007. Wind speed data have been supplied from the US NOAA only for three locations in west, south, and center during the same time frame as temperature and precipitation. Humidity data were available only at two locations, south from NOAA and center from AWS.

In this study, the satellite data used over Seoul covers the area with following coordinates: top 37.701364, bottom 37.428478 , left 126.7642, and right 127.1835 . AOD sat is obtained at $550 \mathrm{~nm}$ from the Moderate Resolution Imaging Spectroradiometer (MODIS)/Terra and $\mathrm{AOD}_{\text {aeronet }}$, at $440 \mathrm{~nm}$, from Aerosol Robotic Network (AERONET) (Table 1). A high correlation coefficient of 0.84 is obtained between $\mathrm{AOD}_{\text {sat }}$ data retrieved from MODIS/Terra satellite and $\mathrm{AOD}_{\text {aeronet }}$ collected at Seoul National University's AERONET site. The Ångström exponent and fine mode fraction (FMF) are used to distinguish aerosols' origin either natural such as dust events or anthropogenic [40]. The FMF is the fraction of the $\mathrm{AOD}_{\text {sat }}$ contributed to by fine aerosols and distinguishes how the aerosols were derived, that is, from dust or anthropogenic origins, by determining the size of the aerosols $[51,52]$.

\section{Results}

3.1. Air Pollutants and Meteorological Parameters. Meteorological parameters such as temperature, precipitation, and wind speed play a pivotal role in air pollutants dynamics and distribution in many different ways $[53,54]$. Here, we have carried out correlation analysis between the four pollutants mentioned in Table 1 and the corresponding meteorological parameters, namely, temperature and precipitation, over the 8 -year period, from 2000 to 2007, taking seasonality into consideration.

All pollutants showed a significant negative correlation with temperature and precipitation before removing seasonality than after removing it, yet with positive correlations among pollutants (Table 2), a result that was partially found by Park et al. [55]. To further investigate the pollutants dependencies on the seasonal component, we have carried another cross-correlation analysis between the aforementioned parameters during spring, summer, fall, and winter seasons (Table 3). The negative correlation coefficient between pollutants and precipitation during all seasons suggests that removal process takes place and affects deposition to a great extent. Yet, the fall season showed the least dependency between pollutants and the meteorological parameters, implying that the local meteorology does not affect pollution concentrations during the fall season. This is owed to the fact that during fall and winter the atmosphere is less stable as compared to summer resulting in more pollutants dispersion 
TABLE 2: The correlation coefficients between temperature, precipitation, and air pollutants: (a) with seasonal effects included and (b) with seasonal effects removed.

(a)

\begin{tabular}{lccccc}
\hline & Pre & $\mathrm{NO}_{2}$ & $\mathrm{CO}$ & $\mathrm{SO}_{2}$ & $\mathrm{PM}_{10}$ \\
\hline Temp. & 0.59 & -0.70 & -0.72 & -0.82 & -0.43 \\
Precip. & & -0.66 & -0.46 & -0.55 & -0.43 \\
$\mathrm{NO}_{2}$ & & & 0.61 & 0.72 & 0.69 \\
$\mathrm{CO}$ & & & & 0.75 & 0.44 \\
$\mathrm{SO}_{2}$ & & & & & 0.44 \\
\hline
\end{tabular}

(b)

\begin{tabular}{lccccc}
\hline & Pre & $\mathrm{NO}_{2}$ & $\mathrm{CO}$ & $\mathrm{SO}_{2}$ & $\mathrm{PM}_{10}$ \\
\hline Temp. & -0.03 & 0.19 & 0.07 & 0.07 & 0.16 \\
Precip. & & -0.16 & -0.13 & -0.26 & -0.06 \\
$\mathrm{NO}_{2}$ & & & 0.22 & 0.23 & 0.40 \\
$\mathrm{CO}$ & & & & 0.39 & 0.39 \\
$\mathrm{SO}_{2}$ & & & & & 0.06 \\
\hline
\end{tabular}

[56]. On the other hand, summer showed a high correlation between $\mathrm{NO}_{2}$ and $\mathrm{PM}_{10}$ as compared to other pollutants during other seasons and this is owed to the high traffic experienced during summer.

The previous analysis was performed by averaging all the meteorological parameters and pollutant data over Seoul, yet we wanted to further investigate the dependence on different regions within Seoul. For that, we selected five sites at the four cardinal directions: east $(127.1 \mathrm{E}, 37.5 \mathrm{~N})$, west $(126.8 \mathrm{E}$, $37.5 \mathrm{~N})$, south $(126.9 \mathrm{E}, 37.5 \mathrm{~N})$, and north $(127.04 \mathrm{E}, 37.6 \mathrm{~N})$, and at the center $(126.9 \mathrm{E}, 37.6 \mathrm{~N})$. Each of these sites has different geological characteristics and processes, for instance, east, north, and south parts are surrounded by mountain and west is close to the ocean. In addition, vehicles and human activities vary; during the daytime the center is crowded as many companies and major offices are located within, yet, the other sites are mixed industrial and residential areas.

It is interesting that the annual mean values of $\mathrm{CO}$ and $\mathrm{SO}_{2}$ at the central location decrease gradually to a minimum in 2003 and in 2002, respectively, where further investigation is needed.

Each pollutant showed different abundances over 10-year averaged concentration at each site. The CO concentration showed notable differences between pollutants. The highest CO concentration is shown at the center $(0.89 \mathrm{ppm})$ then the order of south, west, east, and north $(0.65,0.62,0.62$, and $0.56 \mathrm{ppm}$, resp.). It could be due to heating from residences and vehicles, the main sources of $\mathrm{CO}$ emission. Generally the center and south experience heavy traffic more than the other sites and less residences and offices exist at the north. The $\mathrm{PM}_{10}$ concentration indicates the highest at the center as $\mathrm{CO}$; however the south site takes place for the lowest. Unexpectedly the highest concentration of $\mathrm{NO}_{2}$ and $\mathrm{SO}_{2}$ occurred at the south site; it could be due to vehicles and industrial activities.

We added wind speed at the center, west, and south (no data for the east and north) sites. According to other studies concentration of the four pollutants, pollutants react sensitively with wind speed [57-59]. Moreover, wind plays an important role of air pollution dispersion [60]. However, the results show low correlation coefficient: only west site shows notable negative correlation with $\mathrm{NO}_{2}(-0.45)$. The west site is the only one place that is not surrounded by mountains, while the other sites are crowed with skyscrapers. This indicates that geological and specific megacity's features are one of important elements to determine pollutants concentration.

3.2. Annual Mean Analysis of the Four Air Pollutant Concentrations. Various pollutants are emitted from many different sources in megacities including Seoul, where high temperature combustion processes, such as from power plants and automobiles, are the main emission sources of $\mathrm{NO}_{2}$ that has been slightly decreasing over the last decade due to the combined effects of various control efforts. However, increasing trends were still observed in some locations with high concentrations of CO [61], derived from vehicles and forest fires as well as $\mathrm{SO}_{2}$ emission from burning fossil fuel and some industrial activities [48]. On the other hand, $\mathrm{PM}_{10}$ emission is strongly connected to different types of natural (dust storms) and anthropogenic sources [48]. Therefore, the $\mathrm{PM}_{10}$ studies are associated with specific dust events [37, 6264]: high occurrences during spring (about $87 \%$ of the annual frequency in Korea) (Figure 2).

The $\mathrm{NO}_{2}$ annual mean in 2008 showed the highest peak (0.0363 ppm) and in 2002 and 2005 showed the lowest. The increasing population and number of cars are the reason for the variations of annual mean because vehicles contribute to more than $70 \%$ of $\mathrm{NO}_{2}$ [48]. Figure 3 supports the variation of annual mean where the highest number of vehicles and population is experienced during 2008, low population and stable vehicles number during the 2003-2005 period, and lowest population but increasing vehicles in 2002 .

The annual mean values showed that $\mathrm{CO}$ concentrations decreased much more than the other pollutants over the 10 -year period. The maximum value $(1.0 \mathrm{ppm})$ is shown in 2000 and all months observed the highest concentration with exception of March and April (the highest March and April value was in 2001). The lowest annual mean is observed during 2005 with 0.63 ppm. The CO monthly means showed high concentrations during winter and low concentrations during summer, is analogous to $\mathrm{NO}_{2}$. These two pollutants show similar concentration tendencies in monthly mean, which is consistent with previous study [61].

$\mathrm{SO}_{2}$ showed two peaks in $2000(0.007 \mathrm{ppm})$ and 2007 $(0.0065 \mathrm{ppm})$ whereas the lowest value is observed in 2002 $(0.005 \mathrm{ppm})$. The annual concentration decreased rapidly from 2000 to 2002, which would suggest that the emission control policies are established since 1995. Nevertheless, it increased again after 2004.

In 2002, the highest $\mathrm{PM}_{10}$ annual value $\left(70.41 \mu \mathrm{g} / \mathrm{m}^{3}\right)$ was recorded and thus could be attributed to dust events. Dust was transported from China to Korea on the 21st of March, with a concentration of $1,153 \mu \mathrm{g} / \mathrm{m}^{3}$ (Figure 4) along with the prevailing wind direction from the west with speed $5.6 \mathrm{~m} / \mathrm{s}$. Kim [37] reported that dust events have significantly 
TABLE 3: The correlation coefficients between temperature and precipitation and air pollutants by season (with seasonal effects).

\begin{tabular}{|c|c|c|c|c|c|c|c|c|c|c|c|c|c|c|c|}
\hline & \multicolumn{5}{|c|}{ Spring } & \multicolumn{5}{|c|}{ Summer } & \multicolumn{5}{|c|}{ Fall } \\
\hline & Pre & $\mathrm{NO}_{2}$ & $\mathrm{CO}$ & $\mathrm{SO}_{2}$ & $\mathrm{PM}_{10}$ & Pre & $\mathrm{NO}_{2}$ & $\mathrm{CO}$ & $\mathrm{SO}_{2}$ & $\mathrm{PM}_{10}$ & Pre & $\mathrm{NO}_{2}$ & $\mathrm{CO}$ & $\mathrm{SO}_{2}$ & $\mathrm{PM}_{10}$ \\
\hline Temp. & 0.55 & -0.16 & -0.38 & -0.51 & -0.22 & 0.16 & -0.74 & 0.0 & -0.32 & -0.56 & 0.54 & -0.77 & -0.64 & -0.79 & -0.70 \\
\hline Precip. & & -0.21 & -0.47 & -0.48 & -0.16 & & -0.46 & -0.14 & -0.50 & -0.43 & & -0.68 & -0.46 & -0.43 & -0.53 \\
\hline $\mathrm{NO}_{2}$ & & & 0.45 & 0.38 & 0.33 & & & 0.35 & 0.48 & 0.80 & & & 0.58 & 0.78 & 0.80 \\
\hline $\mathrm{CO}$ & & & & 0.65 & 0.49 & & & & 0.30 & 0.52 & & & & 0.69 & 0.74 \\
\hline $\mathrm{SO}_{2}$ & & & & & 0.04 & & & & & 0.49 & & & & & 0.63 \\
\hline
\end{tabular}

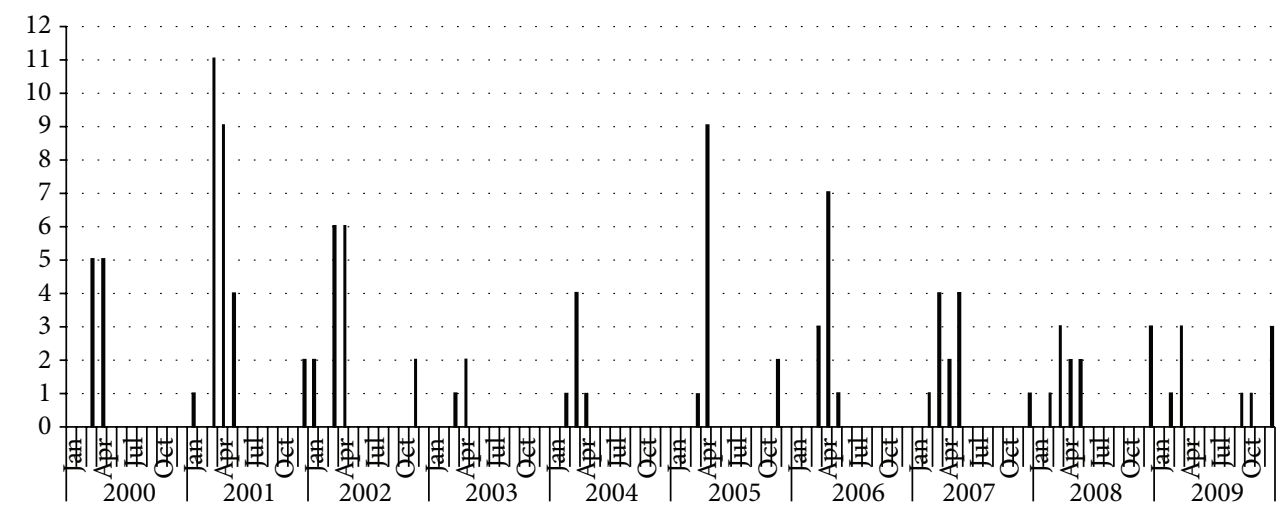

FIGURE 2: Dust event frequencies over the 10 years period.

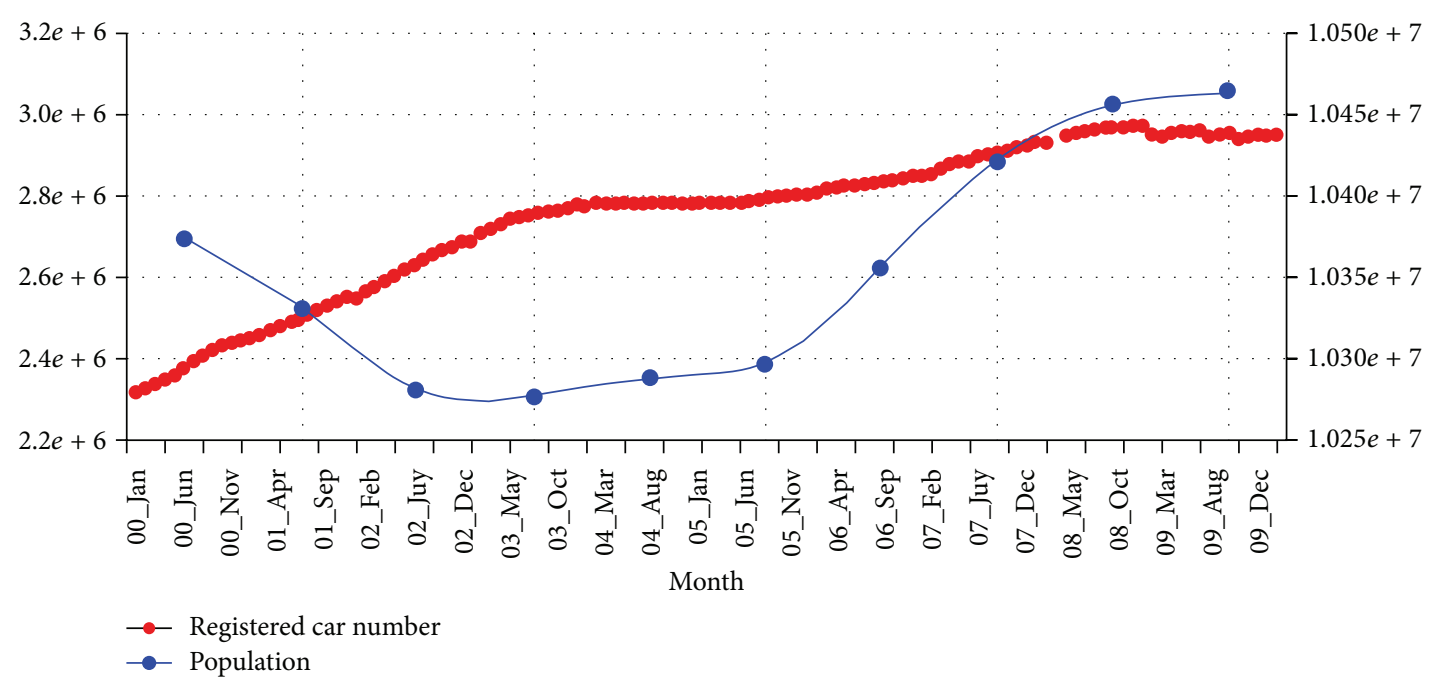

FIGURE 3: The number of registered car and population between 2000 and 2009.

increased during the 3 years from 2000 to 2002 and it has been increasing continuously since the 1980 . The second highest peak was in 2007 with $62.74 \mu \mathrm{g} / \mathrm{m}^{3}$, is much lower value than first peak even though dust events were more frequent in 2007 than in 2002.

3.3. Monthly Mean Analysis of the Four Air Pollutant Concentrations. The monthly $\mathrm{NO}_{2}$ trends showed the same pattern as previous studies, that is, low concentrations during summer and high concentrations during winter [39, 54]. Figure 6(a) indicates that the $\mathrm{NO}_{2}$ in first (2000) and sixth (2005) low peaks showed the lowest monthly mean values during the summer. On the other hand, $\mathrm{NO}_{2}$ in ninth peak (2007) showed the highest monthly mean value. During the summer, the rapid decreasing concentration of $\mathrm{NO}_{2}$ is due to atmospheric conditions such as amounts of humidity and precipitation [65, 66]: according to Haberer et al. 2006 [65] 


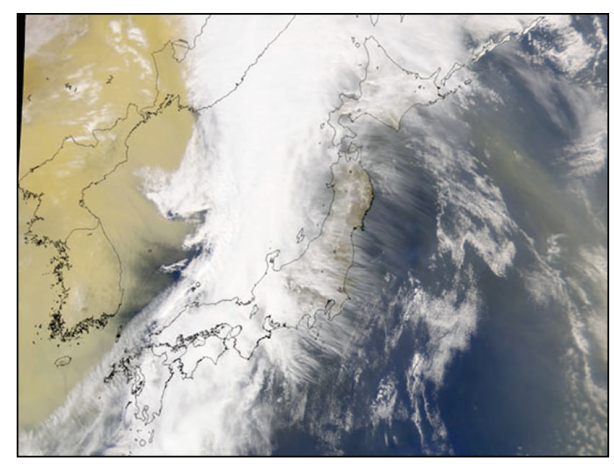

FIgURE 4: MODIS Terra image for 21 March, 2002, dust storm. Dust is lighter than the background in this true color MODIS-Terra image.

study, the minimum concentration of $\mathrm{NO}_{2}$ investigated in July and $\mathrm{NO}_{2}$ showed positive correlation with humidity. However, Korea experiences Monsoon every summer (this season takes most amount of annual precipitation); thus high humidity and huge amount of precipitation exist.

The CO monthly mean concentration showed the first peak during the winter of 2000 that was much higher than in the other years (Figure 6(b)). This could be due to the main sources of district heating and vehicular emission. According to the Ministry of Environment reports, the emission from vehicle takes a fist rank position and the consumption of fuel is the second reason of the entire CO emission [48]. The number of registered car has been increasing since 2000; however, the trend of oil consumption has been decreasing, exactly same pattern as the $\mathrm{CO}$ annual mean, except for the year 2000 (Figure 5). It indicates that CO concentration is significantly dependent on human activities.

The monthly pattern of the $\mathrm{SO}_{2}$ concentration mostly showed the same behavior as that of $\mathrm{CO}$ and $\mathrm{NO}_{2}$, with the highest concentrations during winter and the lowest during the summer (Figure 6(c)). According to Lalas et al. [67], in Greece, a low concentration was observed in late summer and early fall because of rain combined with a deep mixed layer. We mentioned above that the monsoon influences Korea during the summer; thus precipitation could explain that the low concentration was observed during summer and could be related to amount of rain and it reacts with precipitation dissimilar to other pollutants.

Figures 4 and 6(d) show that the 2002 dust storm was recorded as an intense event much stronger than other dust events in other years $[68,69]$. The monthly mean of $\mathrm{PM}_{10}$ during spring season always takes high values during a year; during the winter it is of higher values than summer and fall seasons. However, the lowest concentrations always occurred during summer season due to the wash-out effect of summer rainfall: the lowest values were recorded in August in 2008, at $31.96 \mu \mathrm{g} / \mathrm{m}^{3}$. Dust storms were definitely one of the main sources of high $\mathrm{PM}_{10}$ concentration [70,71] during spring season. Sabbah and Hasan [72] found that the increase in wind speed is related to the increase of the concentration of dust particles during spring over the Solar Village (Riyadh,
Saudi Arabia). Generally, during the spring the wind blows strongly from west to east over Korea.

3.4. Analysis of Pollutant Sources. In Sections 3.2 and 3.3, we show temporal characteristic of each pollutant with some possible reasons for 10 years period in Seoul metropolitan area. However, it has limitation of recognizing their origin; therefore we used satellite data $\left(\mathrm{AOD}_{\text {sat }}\right.$, Angström exponent, and FMF) to distinguish their origins.

The satellite results indicate that $\mathrm{AOD}_{\text {sat }}$ increased from March to May, as expected due to the dust storms during the spring. All years during this time show AOD increasing with both low and high Ångström exponent and FMF representing a possible mixing scenario. During March 2002, a strong dust storm occurred (Figure 4), where the Ångström exponent, $\mathrm{AOD}_{\text {sat }}$, and FMF values were $0.9,0.45$, and 0.1 , respectively (Figure 7). These values suggest that this dusty event contains aerosols derived not only from natural sources but also from anthropogenic ones.

Unlikely, all Ångström exponent values were higher than 1 with decreasing $\mathrm{AOD}_{\text {sat }}$ values, while the FMF showed highest values (Figure 7) during the summer. For better understanding of distribution and origin of air pollution, we categorized the condition of atmospheric using $\mathrm{AOD}_{\text {sat }}$ and Ångström exponent values as same as "clean" with AOD $\leq$ 0.06 , "dust" with AOD $>0.06$ and Ångström exponent $<0.25$, and "pollution" with Ångström exponent > 1.0, and other cases are classified as "mixed" [21]. The results show that the conditions of atmospheric over Seoul only have the cases of "mixed" and "pollution." In addition, most of the pollution occurs from May to October and mixed condition exists from November to April.

3.5. Volume Size Distribution Variability. Here we investigate the variation of the volume size distributions (VSD) as a function of the particle geometric mean radius for Anmyeon located $180 \mathrm{~km}$ from Seoul during the period 2000 to 2007 except for 2003 over west-ward direction as well as over Seoul for 4 years from 2000 till 2003 (Figure 8). The VSD was inverted from the AERONT observations at Anmyeon and Seoul, it helps understand local aerosol properties and variation $[73,74]$. Figure $8(b)$ displays the variation of the VSD $(d V / d \ln R)$ with a high magnitude of coarse mode peaking during the years 2005, 2006, and 2007 as compared to the previous years. The year 2002 has the highest concentration of coarse particles at Anmyeon due to the dust storm of 21 March, 2002. It peaks at $\sim 3 \mu \mathrm{m}$ geometric mean radius with partial contribution for the fine particles fraction.

We got a good correlation $(r=0.60)$ between the monthly values of AODaeronet collected at Seoul National University's AERONET site and the corresponding PM10 values during 2002, when a major dust event occurred, observed close to Seoul National University (Latitude: 37.45, Longitude: 126.9), and a correlation coefficient of -0.45 between Angstrom exponent and PM10. Sabbah et al. 2012 [75] found a good inverse correlation $(r=-0.62)$ between the Angström exponent and $\mathrm{AOD}_{\text {sat }}$ using Terra/MODIS satellite collections. They interpreted that as evidence of high 


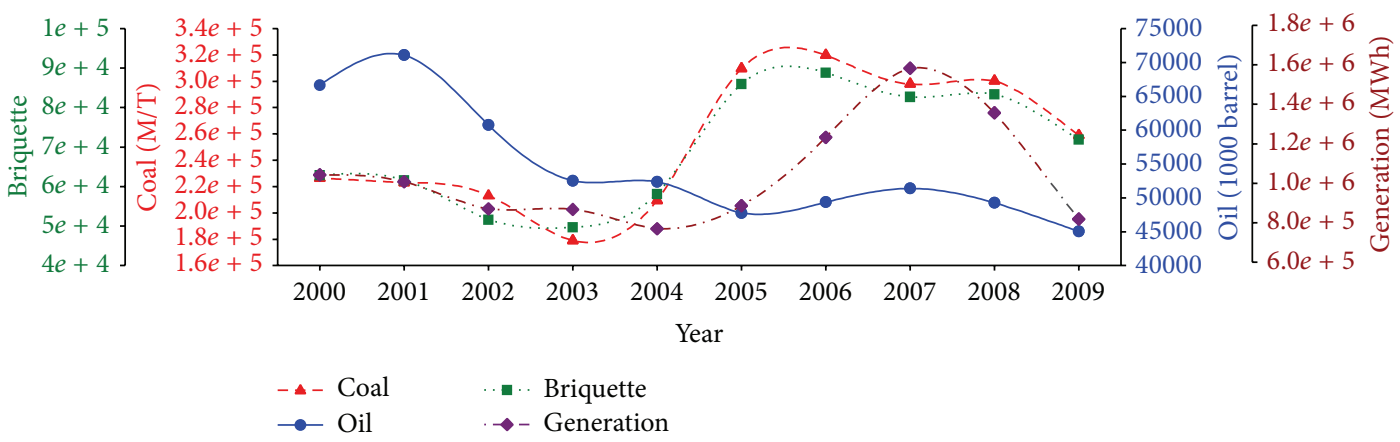

FIGURE 5: Annual means of coal and oil consumption and yield of briquette and generated.

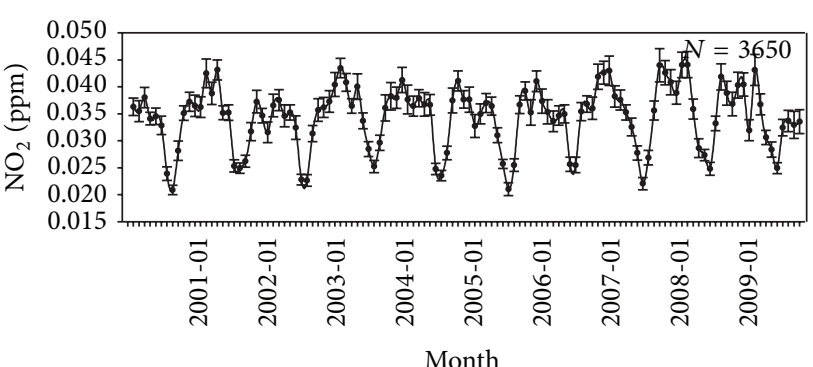

(a)

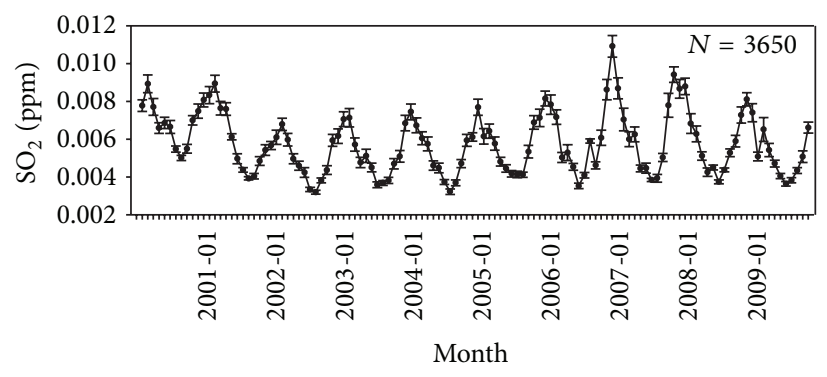

(c)

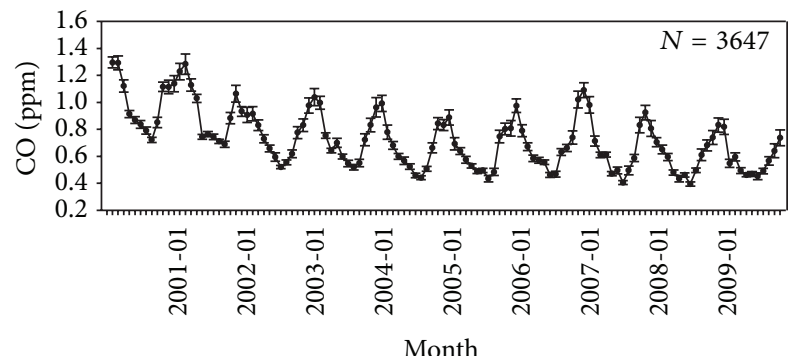

(b)

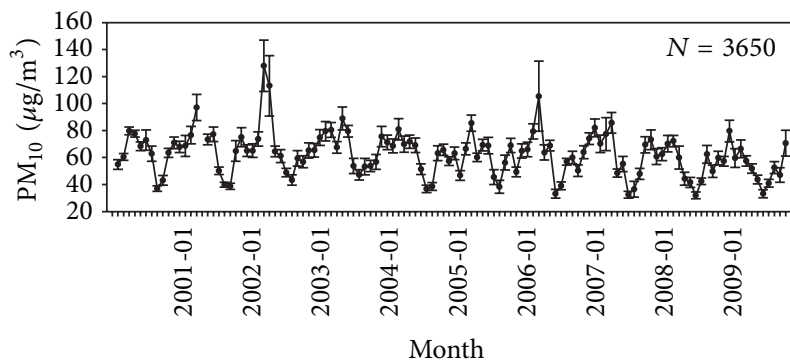

(d)

FIgURE 6: Monthly mean variations of (a) $\mathrm{NO}_{2}$, (b) $\mathrm{CO}$, (c) $\mathrm{SO}_{2}$, and (d) $\mathrm{PM}_{10}$ between 2000 and 2009.

dust concentration. It supports that the dust storm in 2002 was high dust concentration. The year 2004 over Anmyeon exhibits the highest concentration of fine particles where the VSD peaks at $0.1 \mu \mathrm{m}$. Figure 8 (d) illustrates the variation of the volume size distributions over Seoul for dust storm occurring on 21 March, 2002. We see a substantial increase in the concentration of the coarse particles at $2.9 \mu \mathrm{m}$ that dominates the aerosol loadings on March 21 as evident from the major dust event over Seoul (Figure 4).

\section{Discussion and Conclusions}

In this study, major air pollutants over Seoul, including $\mathrm{NO}_{2}, \mathrm{CO}, \mathrm{SO}_{2}$, and $\mathrm{PM}_{10}$, were examined, revealing specific tendencies and characteristics, which can be attributed to natural and anthropogenic sources, as well as changing meteorological factors. The significant relationships between air pollution and temperature/precipitation exist due to the seasonality particularly; the strongest impacts were observed during the fall.

The annual mean results showed peak in different year related to different anthropogenic sources. This is evident from the increase in the cumulative number of registered car per month, rapid increase in population, high coal consumption, and the briquette yield. The dust storms, during the spring and winter, indicate mixed or pollution conditions. It means that even though dust storm contains not only natural aerosols but also aerosols from anthropogenic sources $[15,20$, $76,77]$. Therefore, the reason for the peaks and minimum values are due to both natural and anthropogenic sources playing a role in the same year. The atmospheric condition during the summer is clearly identified as pollution, although all four pollutants show the lowest concentration. On the other hand, during the fall (highly affected by seasonality), it showed the mixed condition.

Satellite data analysis distinguished the pollutants origins and VSD. It indicates that the year 2007 contains small 

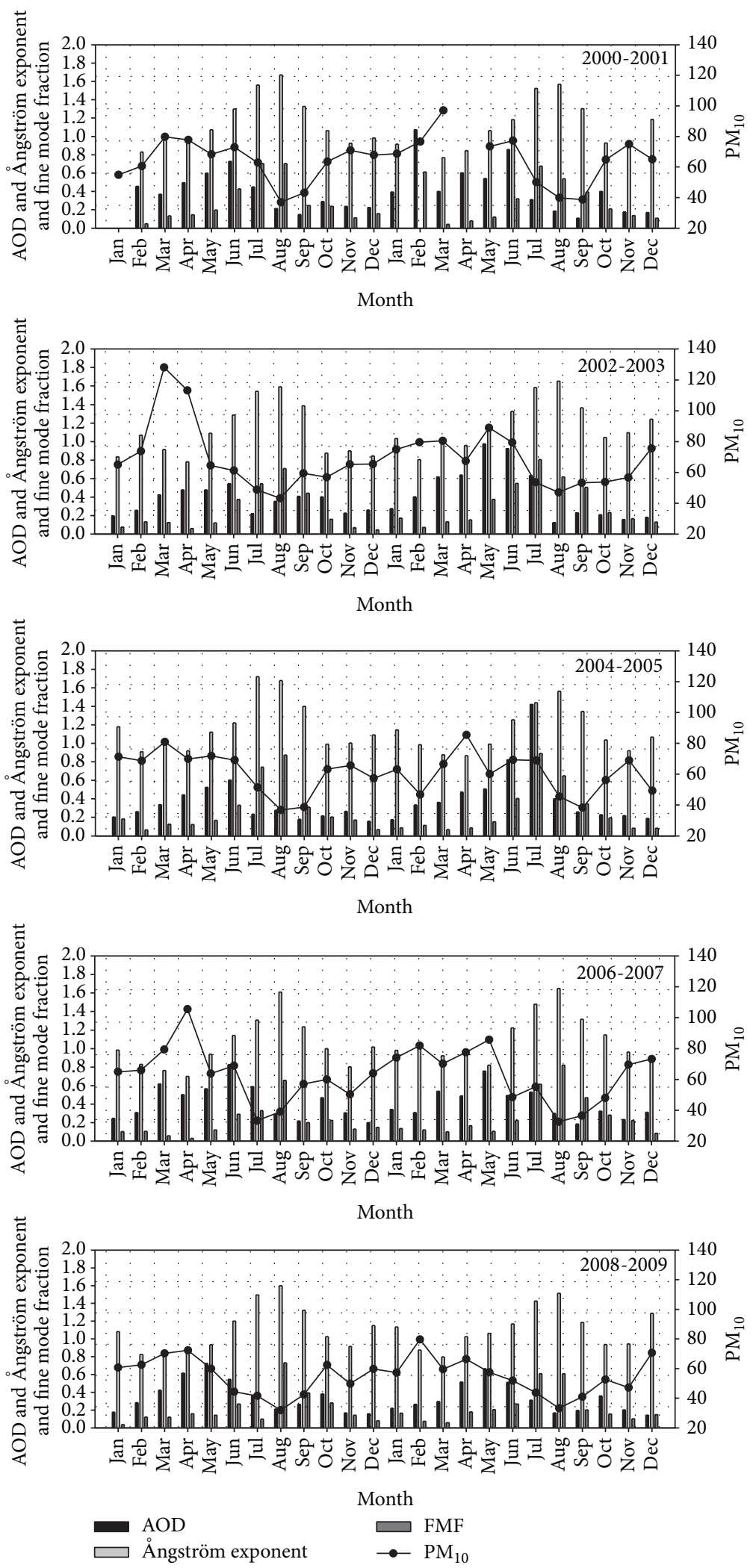

Figure 7: Satellite data ( $\mathrm{AOD}_{\text {sat }}$, Ångström exponent, and FMF) with $\mathrm{PM}_{10}$ (2000 to 2009). 


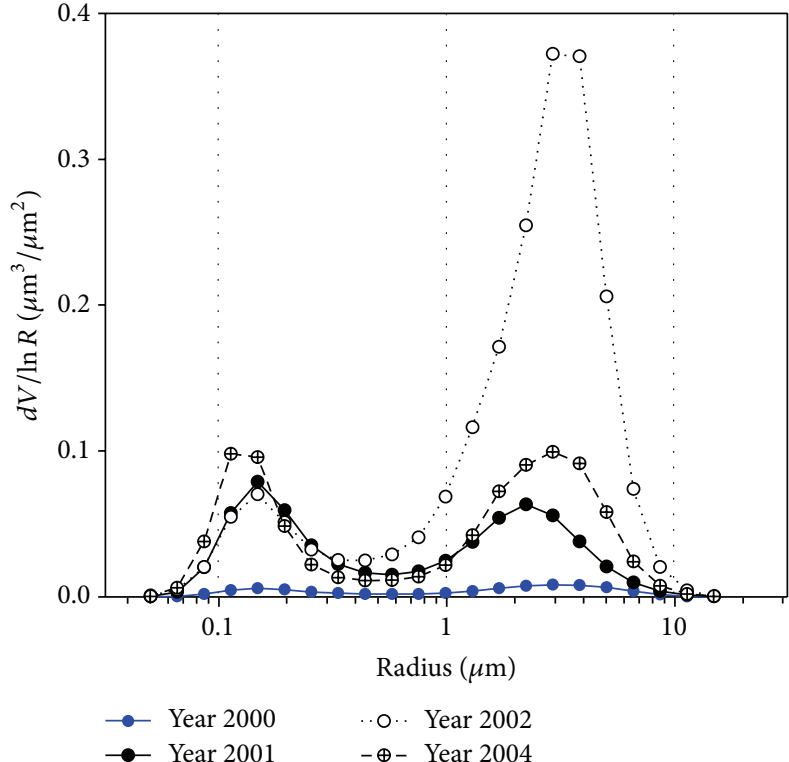

(a)

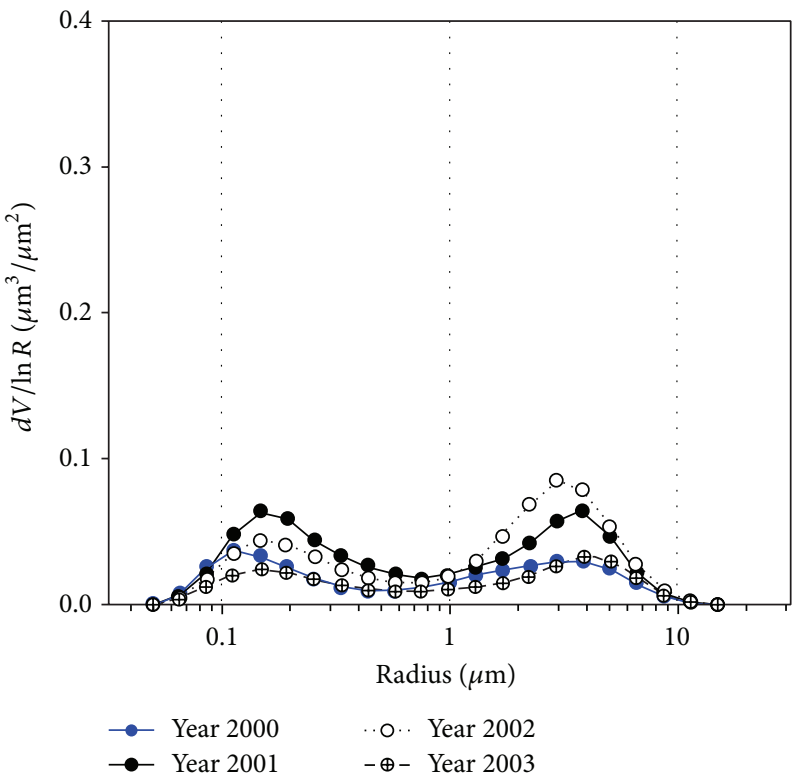

(c)

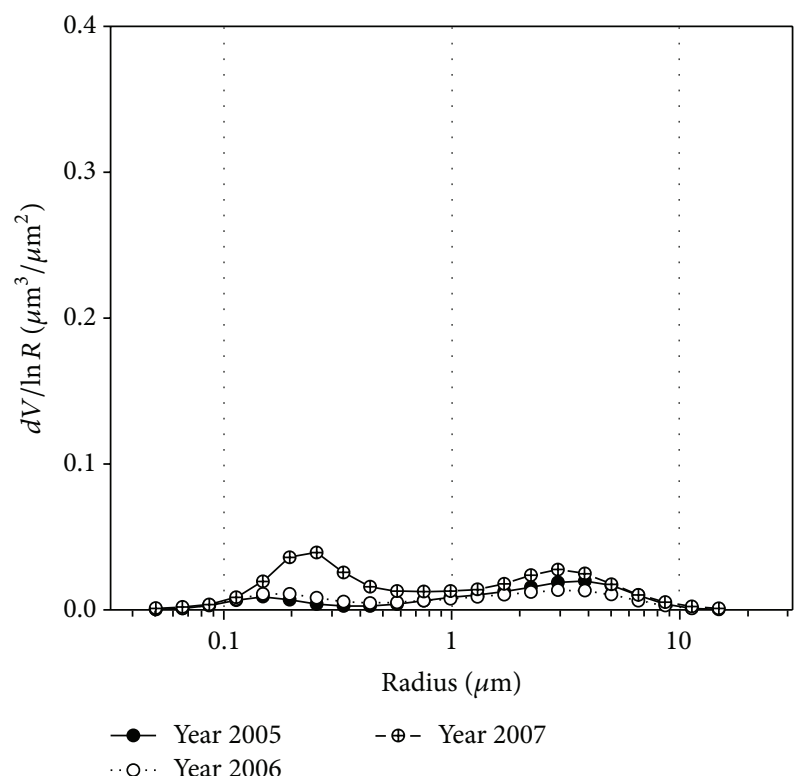

(b)

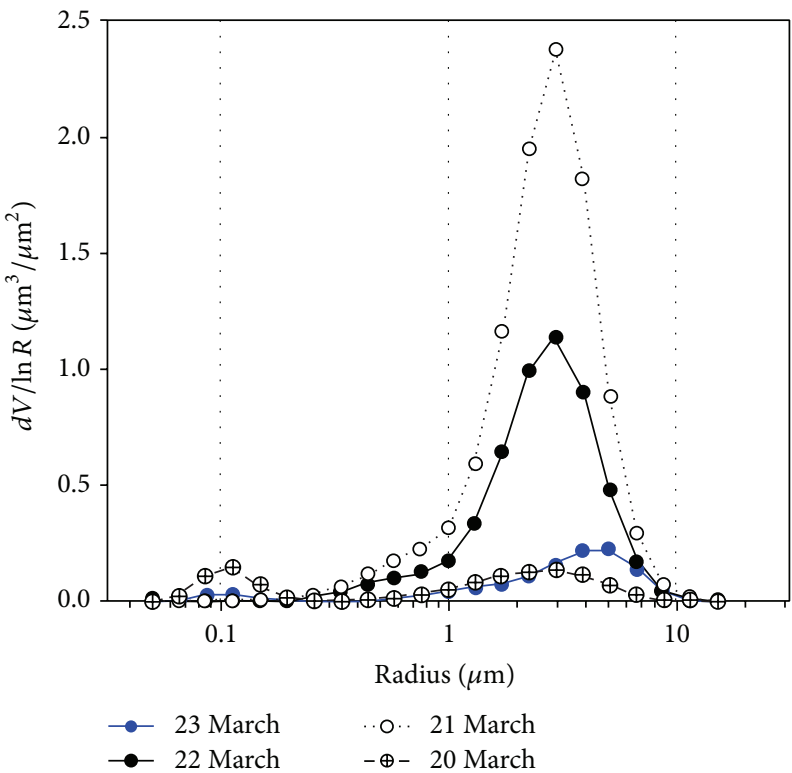

(d)

FIGURE 8: Variation of aerosol volume size distribution: (a) annual variation over Anmyeon for $N=63,2000, N=177,2001, N=42,2002$, and $N=209,2004$, (b) over Anmyeon for $N=117,2005, N=174,2006$, and $N=189,2007$, (c) over Seoul from for $N=15,2000, N=8$, 2001, $N=106,2002$, and $N=14,2003$, and (d) daily variation over Seoul before, during, and after the dust storm of 21 March $2002 . N$ is the number of days used.

size particle more than the other years: it implies that anthropogenic aerosol was predominant. In addition, anthropogenic aerosols increased in 2004 at Anmyeon rather than 2000, even though many policies have been established for air pollution: the radius of anthropogenic aerosols was found between 0.1 and $0.25 \mu \mathrm{m}[78,79]$. The effective controls for air pollution in megacities, such as Seoul, must consider natural as well as anthropogenic sources when formulating laws to restrict pollutant emissions. Therefore, policy decisions need to be more elaborated to result in better air quality over Seoul.

\section{Conflict of Interests}

The authors declare that there is no conflict of interests regarding the publication of this paper.

\section{Acknowledgments}

Dr. El-Askary would like to acknowledge the partial support of this work for the US collaborators by the NSF Grant 0922772. Furthermore, the authors would like also 
to acknowledge the use of the Samueli Laboratory in Computational Sciences in the Schmid College of Science and Technology, Chapman University, for image processing and data analysis. The authors would like also to acknowledge Ms. Hyun-Ah Choi and Mr. Taehyub Kwon for helping in the ground data preparation process.

\section{References}

[1] T. Abe, Y. Tokuda, S. Ohde, S. Ishimatsu, T. Nakamura, and R. B. Birrer, "The relationship of short-term air pollution and weather to ED visits for asthma in Japan," American Journal of Emergency Medicine, vol. 27, no. 2, pp. 153-159, 2009.

[2] B. R. Gurjar, T. M. Butler, M. G. Lawrence, and J. Lelieveld, "Evaluation of emissions and air quality in megacities," Atmospheric Environment, vol. 42, no. 7, pp. 1593-1606, 2008.

[3] K.-H. Kim, Y.-J. Choi, and M.-Y. Kim, "The exceedance patterns of air quality criteria: a case study of ozone and nitrogen dioxide in Seoul, Korea between 1990 and 2000," Chemosphere, vol. 60, no. 4, pp. 441-452, 2005.

[4] M. Lee, J.-A. Kim, Y.-M. Kim, and G. Lee, "Characteristics of atmospheric hydrogen peroxide variations in Seoul megacity during 2002-2004," Science of the Total Environment, vol. 393, no. 2-3, pp. 299-308, 2008.

[5] T. Takemura, T. Nakajima, T. Nozawa, and K. Aoki, "Simulation of future aerosol distribution, radiative forcing, and long-range transport in East Asia," Journal of the Meteorological Society of Japan, vol. 79, no. 6, pp. 1139-1155, 2001.

[6] S. B. Mazon, I. Riipinen, D. M. Schultz et al., "Classifying previously undefined days from eleven years of aerosol-particlesize distribution data from the SMEAR II station, Hyytiälä, Finland," Atmospheric Chemistry and Physics, vol. 9, no. 2, pp. 667-676, 2009.

[7] J. Huang, C. Zhang, and J. M. Prospero, "Large-scale effect of aerosols on precipitation in the West African Monsoon region," Quarterly Journal of the Royal Meteorological Society, vol. 135, no. 640, pp. 581-594, 2009.

[8] C. Ichoku, R. Levy, Y. J. Kaufman et al., "Analysis of the performance characteristics of the five-channel Microtops II Sun photometer for measuring aerosol optical thickness and precipitable water vapor," Journal of Geophysical Research D: Atmospheres, vol. 107, no. 13, pp. AAC-5-1-AAC-5-17, 2002.

[9] O. Torres, P. K. Bhartia, J. R. Herman, A. Sinyuk, P. Ginoux, and B. Holben, "A long-term record of aerosol optical depth from TOMS observations and comparison to AERONET measurements," Journal of the Atmospheric Sciences, vol. 59, no. 3, pp. 398-413, 2002.

[10] G. A. D’Almeida, P. Koepke, and E. P. Shettle, Atmospheric Aerosols: Global Climatology and Radiative Characteristics, A. Deepak Publishing, Hampton, Va, USA, 1991.

[11] E. P. Shettle, "Optical and radiative properties of a desert aerosol model," in Proceedings of the International Radiation Symposium on Current Problems in Atmospheric Radiation August 1984, vol. 1, pp. 21-28, 1986.

[12] D. Tanre, P. Y. Deschamps, C. Devaux, and M. Herman, "Estimation of Saharan aerosol optical thickness from blurring effects in Thematic Mapper data," Journal of Geophysical Research: Atmosheres, vol. 93, no. 12, pp. 15955-15964, 1988.

[13] D. Tanré and M. Legrand, "On the satellite retrieval of Saharan dust optical thickness over land: two different approaches," Journal of Geophysical Research: Atmospheres, vol. 96, no. 3, pp. 5221-5227, 1991.
[14] A. Vukovic, M. Vujadinovic, G. Pejanovic et al., "Numerical simulation of 'an American haboob"' Atmospheric Chemistry and Physics, vol. 14, no. 7, pp. 3211-3230, 2014.

[15] H. El-Askary, R. Farouk, C. Ichoku, and M. Kafatos, "Transport of dust and anthropogenic aerosols across Alexandria, Egypt," Annales Geophysicae, vol. 27, no. 7, pp. 2869-2879, 2009.

[16] H. El-Askary and M. Kafatos, "Dust storm and black cloud influence on aerosol optical properties over Cairo and the Greater Delta region, Egypt," International Journal of Remote Sensing, vol. 29, no. 24, pp. 7199-7211, 2008.

[17] B. Grobéty, R. Gieré, V. Dietze, and P. Stille, "Airborne particles in the urban environment," Elements, vol. 6, no. 4, pp. 229-234, 2010.

[18] B. K. Lee, H. K. Lee, and N.-Y. Jun, "Analysis of regional and temporal characteristics of PM10 during an Asian dust episode in Korea," Chemosphere, vol. 63, no. 7, pp. 1106-1115, 2006.

[19] G. M. Marcazzan, S. Vaccaro, G. Valli, and R. Vecchi, "Characterisation of $\mathrm{PM}_{10}$ and $\mathrm{PM}_{2.5}$ particulate matter in the ambient air of Milan (Italy)," Atmospheric Environment, vol. 35, no. 27, pp. 4639-4650, 2001.

[20] A. K. Prasad and R. P. Singh, "Changes in aerosol parameters during major dust storm events (2001-2005) over the IndoGangetic Plains using AERONET and MODIS data," Journal of Geophysical Research D: Atmospheres, vol. 112, no. 9, Article ID D09208, 2007.

[21] I. Sabbah, C. Ichoku, Y. J. Kaufman, and L. Remer, "Full year cycle of desert dust spectral optical thickness and precipitable water vapor over Alexandria, Egypt," Journal of Geophysical Research D: Atmospheres, vol. 106, no. 16, pp. 18305-18316, 2001.

[22] H. El-Askary, "Air pollution impact on Aerosol Variability over mega cities using Remote Sensing Technology: case study, Cairo," Journal of Remote Sensing and Space Science, vol. 9, pp. 31-40, 2006.

[23] Y. Aboel Fetouh, H. El Askary, M. El Raey, M. Allali, W. A. Sprigg, and M. Kafatos, "Annual patterns of atmospheric pollutions and episodes over Cairo Egypt," Advances in Meteorology, vol. 2013, Article ID 984853, 11 pages, 2013.

[24] W. A. Sprigg, S. Nickovic, J. N. Galgiani et al., "Regional dust storm modeling for health services: the case of valley fever," Aeolian Research, vol. 14, pp. 53-73, 2014.

[25] S. W. Kim, S. C. Yoon, J. Kim, and S. Y. Kim, "Seasonal and monthly variations of columnar aerosol optical properties over east Asia determined from multi-year MODIS, LIDAR, and AERONET Sun/sky radiometer measurements," Atmospheric Environment, vol. 41, no. 8, pp. 1634-1651, 2007.

[26] J. Kim, S. C. Yoon, A. Jefferson, and S. W. Kim, "Aerosol hygroscopic properties during Asian dust, pollution, and biomass burning episodes at Gosan, Korea in April 2001," Atmospheric Environment, vol. 40, no. 8, pp. 1550-1560, 2006.

[27] S. Ramachandran and T. A. Rajesh, "Black carbon aerosol mass concentrations over Ahmedabab, an urban location in western India: comparison with urban sites in Asia, Europe, Canada, and the United States," Journal of Geophysical Research D: Atmospheres, vol. 112, no. 6, 2007.

[28] S.-W. Kim, S.-C. Yoon, A. Jefferson et al., "Aerosol optical, chemical and physical properties at Gosan, Korea during Asian dust and pollution episodes in 2001," Atmospheric Environment, vol. 39, no. 1, pp. 39-50, 2005.

[29] J. M. Baldasano, E. Valera, and P. Jiménez, "Air quality data from large cities," Science of the Total Environment, vol. 307, no. 1-3, pp. 141-165, 2003. 
[30] S. K. Guttikunda, G. R. Carmichael, G. Calori, C. Eck, and J. H. Woo, "The contribution of megacities to regional sulfur pollution in Asia," Atmospheric Environment, vol. 37, no. 1, pp. 11-22, 2003.

[31] W. K. Jo, I. H. Yoon, and C. W. Nam, "Analysis of air pollution in two major Korean cities: trends, seasonal variations, daily 1hour maximum versus other hour-based concentrations, and standard exceedances," Environmental Pollution, vol. 110, no. 1, pp. 11-18, 2000.

[32] A. K. Prasad, H. El-Askary, and M. Kafatos, "Implications of high altitude desert dust transport from Western Sahara to Nile Delta during biomass burning season," Environmental Pollution, vol. 158, no. 11, pp. 3385-3391, 2010.

[33] K.-H. Tseng, J.-L. Wang, M.-T. Cheng, and B.-J. Tsuang, "Assessing the relationship between air mass age and summer ozone episodes based on photochemical indices," Aerosol and Air Quality Research, vol. 9, no. 2, pp. 149-171, 2009.

[34] S.-C. Chang and C.-T. Lee, "Evaluation of the temporal variations of air quality in Taipei City, Taiwan, from 1994 to 2003," Journal of Environmental Management, vol. 86, no. 4, pp. 627635, 2008.

[35] H. El-Askary, A. K. Prasad, G. Kallos, M. El-Raey, and M. Kafatos, "Analyzing black cloud dynamics over cairo, nile delta region and alexandria using aerosols and water vapor data," in Air Quality-Models and Applications, chapter 12, InTECH, Vienna, Austria, 2011.

[36] F. Geng, Q. Zhang, X. Tie et al., "Aircraft measurements of $\mathrm{O}_{3}$, $\mathrm{NO}_{x}, \mathrm{CO}, \mathrm{VOCs}$, and $\mathrm{SO}_{2}$ in the Yangtze River Delta region," Atmospheric Environment, vol. 43, no. 3, pp. 584-593, 2009.

[37] J. Kim, "Transport routes and source regions of Asian dust observed in Korea during the past 40 years (1965-2004)," Atmospheric Environment, vol. 42, no. 19, pp. 4778-4789, 2008.

[38] D. Mage, G. Ozolins, P. Peterson et al., "Urban air pollution in megacities of the world," Atmospheric Environment, vol. 30, no. 5, pp. 681-686, 1996.

[39] J. An, H. Ueda, Z. Wang, K. Matsuda, M. Kajino, and X. Cheng, "Simulations of monthly mean nitrate concentrations in precipitation over East Asia," Atmospheric Environment, vol. 36, no. 26, pp. 4159-4171, 2002.

[40] H. M. El-Askary, S. Sarkar, M. Kafatos, and T. A. El-Ghazawi, "A multisensor approach to dust storm monitoring over the nile delta," IEEE Transactions on Geoscience and Remote Sensing, vol. 41, no. 10, pp. 2386-2391, 2003.

[41] H. S. Marey, J. C. Gille, H. M. El-Askary, E. A. Shalaby, and M. E. El-Raey, "Aerosol climatology over Nile Delta based on MODIS, MISR and OMI satellite data," Atmospheric Chemistry and Physics, vol. 11, no. 20, pp. 10637-10648, 2011.

[42] H. S. Marey, J. C. Gille, H. M. El-Askary, E. A. Shalaby, and M. E. El-Raey, "Study of the formation of the 'black cloud' and its dynamics over Cairo, Egypt, using MODIS and MISR sensors," Journal of Geophysical Research D: Atmospheres, vol. 115, no. 21, 2010.

[43] I. Sabbah, "Impact of aerosol on air temperature in Kuwait," Atmospheric Research, vol. 97, no. 3, pp. 303-314, 2010.

[44] Y.-S. Choi, C.-H. Ho, D. Chen, Y.-H. Noh, and C.-K. Song, "Spectral analysis of weekly variation in $\mathrm{PM}_{10}$ mass concentration and meteorological conditions over China," Atmospheric Environment, vol. 42, no. 4, pp. 655-666, 2008.

[45] H. S. Lee, C.-M. Kang, B.-W. Kang, and H.-K. Kim, "Seasonal variations of acidic air pollutants in Seoul, South Korea," Atmospheric Environment, vol. 33, no. 19, pp. 3143-3152, 1999.
[46] Korea Meteorological Administration, Annual Climate Report, Korea Meteorological Administration, 2000, (korean), http://www.kma.go.kr.

[47] Y. Chae, "Co-benefit analysis of an air quality management plan and greenhouse gas reduction strategies in the Seoul metropolitan area," Environmental Science and Policy, vol. 13, no. 3, pp. 205-216, 2010.

[48] Ministry of Environment Republic of Korea, Annual report of ambientair quality in Korea, 2002, 2003, 2007, 2008 and 2009 (Korean), http://library.me.go.kr.

[49] A. Agarwal, H. M. El-Askary, T. El-Ghazawi, M. Kafatos, and J. Le-Moigne, "Hierarchical PCA techniques for fusing spatial and spectral observations with application to MISR and monitoring dust storms," IEEE Geoscience and Remote Sensing Letters, vol. 4, no. 4, pp. 678-682, 2007.

[50] H.-J. Kwon, S.-H. Cho, Y. Chun, F. Lagarde, and G. Pershagen, "Effects of the Asian dust events on daily mortality in Seoul, Korea," Environmental Research, vol. 90, no. 1, pp. 1-5, 2002.

[51] T. A. Jones and S. A. Christopher, "MODIS derived fine mode fraction characteristics of marine, dust, and anthropogenic aerosols over the ocean, constrained by GOCART, MOPITT, and TOMS," Journal of Geophysical Research D: Atmospheres, vol. 112, no. 22, Article ID D22204, 2007.

[52] Y. J. Kaufman, O. Boucher, D. Tanré, M. Chin, L. A. Remer, and T. Takemura, "Aerosol anthropogenic component estimated from satellite data," Geophysical Research Letters, vol. 32, no. 17, Article ID L17804, pp. 1-4, 2005.

[53] H. S. Lee, C.-M. Kang, B.-W. Kang, and H.-K. Kim, "Seasonal variations of acidic air pollutants in Seoul, South Korea," Atmospheric Environment, vol. 33, no. 19, pp. 3143-3152, 1999.

[54] X. K. Wang and W. Z. Lu, "Seasonal variation of air pollution index: Hong Kong case study," Chemosphere, vol. 63, no. 8, pp. 1261-1272, 2006.

[55] I. S. Park, D. G. Rhee, and I. G. Kang, "The meteorological factors covering $\mathrm{SO}_{2}$ concentrations during the wintertime in Seoul area," Journal of Korean Society for Atmospheric Environment, vol. 7, pp. 96-104, 1991 (Korean).

[56] H. K. Elminir, "Dependence of urban air pollutants on meteorology," Science of the Total Environment, vol. 350, no. 1-3, pp. 225-237, 2005.

[57] L. Huang, C.-S. Yuan, G. Wang, and K. Wang, "Chemical characteristics and source apportionment of PM10 during a brown haze episode in Harbin, China," Particuology, vol. 9, no. 1, pp. 32-38, 2011.

[58] Y. Ma, Y. Wang, N. Liu, and Y. Hong, "Analysis of inhalable particulate matter $\mathrm{PM}_{10}$ and $\mathrm{PM}_{2.5}$ pollution levels in grouped cities of Central Liaoning Province," China Powder Science and Technology, no. 1, pp. 9-13, 2010.

[59] C.-C. Wen and H.-H. Yeh, "Comparative influences of airborne pollutants and meteorological parameters on atmospheric visibility and turbidity," Atmospheric Research, vol. 96, no. 4, pp. 496-509, 2010.

[60] P. Kastner-Klein, R. Berkowicz, and E. J. Plate, "Modelling of vehicle-induced turbulence in air pollution studies for streets," International Journal of Environment and Pollution, vol. 14, no. 1-6, pp. 496-507, 2000.

[61] A. Bigi and R. M. Harrison, "Analysis of the air pollution climate at a central urban background site," Atmospheric Environment, vol. 44, no. 16, pp. 2004-2012, 2010.

[62] C.-H. Kim, S.-U. Park, and C.-K. Song, "A simple semiempirical photochemical model for the simulation of ozone 
concentration in the Seoul metropolitan area in Korea," Atmospheric Environment, vol. 39, no. 30, pp. 5597-5607, 2005.

[63] S.-W. Kim, S.-C. Yoon, J. Kim, J.-Y. Kang, and N. Sugimoto, "Asian dust event observed in Seoul, Korea, during 29-31 May 2008: analysis of transport and vertical distribution of dust particles from lidar and surface measurements," Science of the Total Environment, vol. 408, no. 7, pp. 1707-1718, 2010.

[64] O. Yi, Y.-C. Hong, and H. Kim, "Seasonal effect of PM10 concentrations on mortality and morbidity in Seoul, Korea: a temperature-matched case-crossover analysis," Environmental Research, vol. 110, no. 1, pp. 89-95, 2010.

[65] K. Haberer, L. Jaeger, and H. Rennenberg, "Seasonal patterns of ascorbate in the needles of Scots Pine (Pinus sylvestris L.) trees: correlation analyses with atmospheric $\mathrm{O}_{3}$ and $\mathrm{NO}_{2}$ gas mixing ratios and meteorological parameters," Environmental Pollution, vol. 139, no. 2, pp. 224-231, 2006.

[66] M. E. Hazenkamp-Von Arx, T. Götschi, U. Ackermann-Liebrich et al., " $\mathrm{PM}_{2.5}$ and $\mathrm{NO}_{2}$ assessment in 21 European study centres of ECRHS II: annual means and seasonal differences," Atmospheric Environment, vol. 38, no. 13, pp. 1943-1953, 2004.

[67] D. P. Lalas, V. R. Veirs, G. Karras, and G. Kallos, "An analysis of the $\mathrm{SO}_{2}$ concentration levels in Athens, Greece," Atmospheric Environment, vol. 16, no. 3, pp. 531-544, 1982.

[68] H. J. Ahn, S. U. Park, and L. S. Chang, "Effect of direct radiative forcing of Asian dust on the meteorological fields in East Asia during an Asian dust event period," Journal of Applied Meteorology and Climatology, vol. 46, no. 10, pp. 1655-1681, 2007.

[69] Z. Batjargal, J. Dulam, and Y. S. Chung, "Dust storms are an indication of an unhealthy environment in East Asia," Environmental Monitoring and Assessment, vol. 114, no. 1-3, pp. 447-460, 2006.

[70] K. Bouchlaghem, B. Nsom, N. Latrache, and H. Haj Kacem, "Impact of Saharan dust on PM10 concentration in the Mediterranean Tunisian coasts," Atmospheric Research, vol. 92, no. 4, pp. 531-539, 2009.

[71] S. Rodríguez, X. Querol, A. Alastuey, G. Kallos, and O. Kakaliagou, "Saharan dust contributions to $\mathrm{PM}_{10}$ and TSP levels in Southern and Eastern Spain," Atmospheric Environment, vol. 35, no. 14, pp. 2433-2447, 2001.

[72] I. Sabbah and F. A. Hasan, "Remote sensing of aerosols over the Solar Village, Saudi Arabia," Atmospheric Research, vol. 90, no. 2-4, pp. 170-179, 2008.

[73] I. Sabbah, A. Nermina, A. A. Mona, A. E. Ali, A. H. Aneesah, and A. A. Nada, "Influence of air quality conditions on asthmatic patient visits in Kuwait," Journal of Allergy and Therapy, vol. 5, no. 6, article 197, 2014.

[74] X. Yang and M. Wenig, "Study of columnar aerosol size distribution in Hong Kong," Atmospheric Chemistry and Physics, vol. 9, no. 16, pp. 6175-6189, 2009.

[75] I. Sabbah, H. F. Al-Mudhaf, A. Al-Kandari, and F. Al-Sharifi, "Remote sensing of desert dust over Kuwait: long-term variation," Atmospheric Pollution Research, vol. 3, no. 1, pp. 95-104, 2012.

[76] E. Hamonou, P. Chazette, D. Balis et al., "Characterization of the vertical structure of Saharan dust export to the Mediterranean basin," Journal of Geophysical Research D: Atmospheres, vol. 104, no. 18, pp. 22257-22270, 1999.

[77] D. G. Kaskaoutis, H. D. Kambezidis, P. T. Nastos, and P. G. Kosmopoulos, "Study on an intense dust storm over Greece," Atmospheric Environment, vol. 42, no. 29, pp. 6884-6896, 2008.
[78] R. G. Kleidman, N. T. O’Neill, L. A. Remer et al., “Comparison of Moderate Resolution Imaging Spectroradiometer (MODIS) and Aerosol Robotic Network (AERONET) remote-sensing retrievals of aerosol fine mode fraction over ocean," Journal of Geophysical Research D: Atmospheres, vol. 110, no. 22, pp. 1-6, 2005.

[79] D. Tanré, Y. J. Kaufman, B. N. Holben et al., "Climatology of dust aerosol size distribution and optical properties derived from remotely sensed data in the solar spectrum," Journal of Geophysical Research D: Atmospheres, vol. 106, no. 16, pp. 1820518217, 2001. 

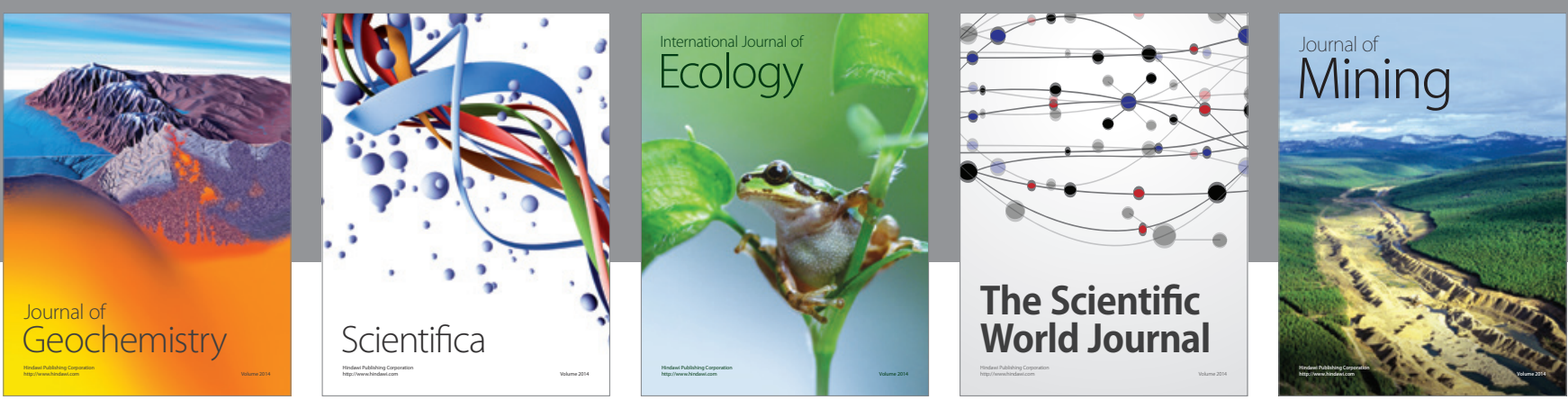

The Scientific World Journal
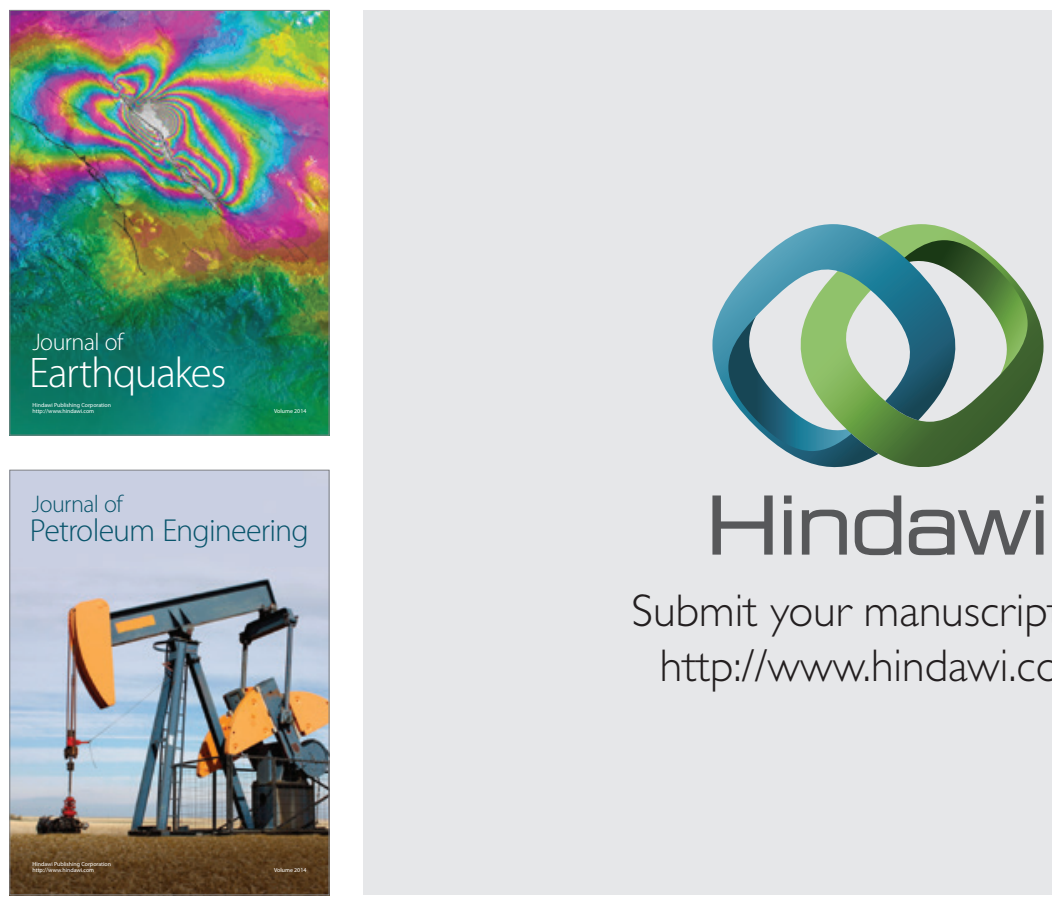

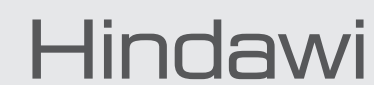

Submit your manuscripts at

http://www.hindawi.com
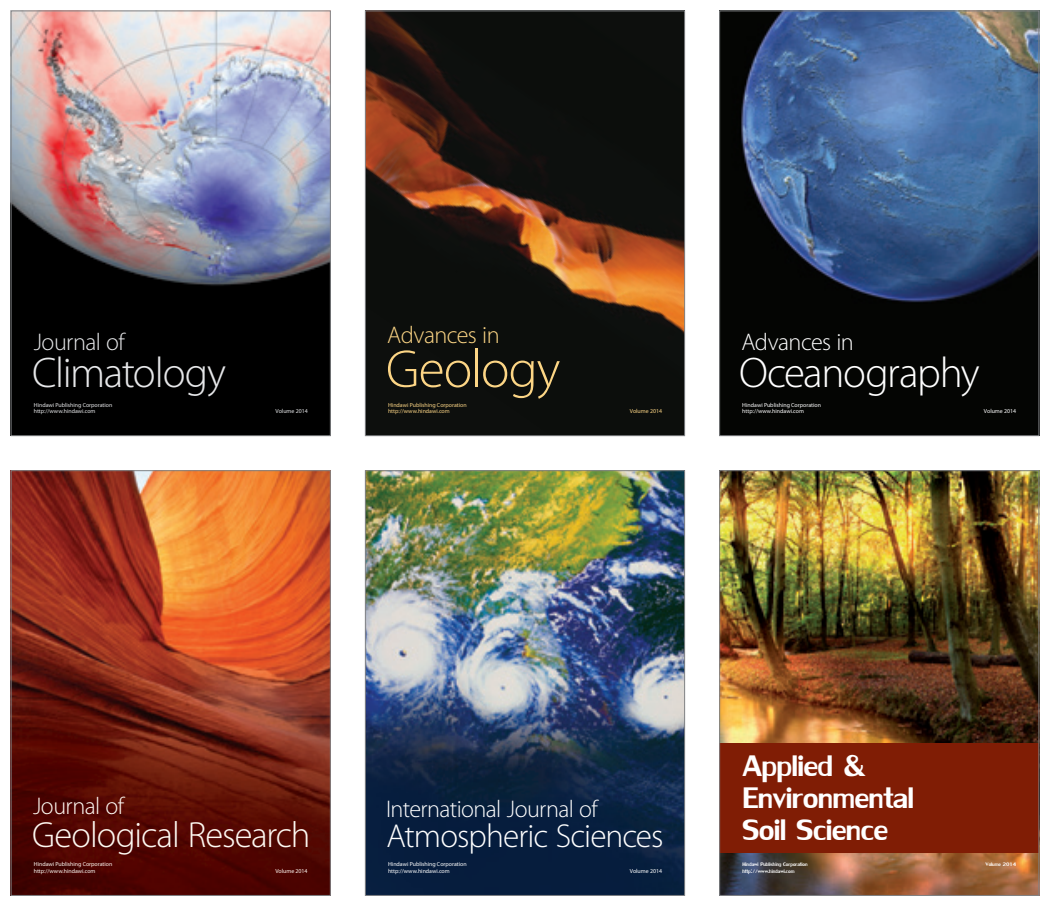
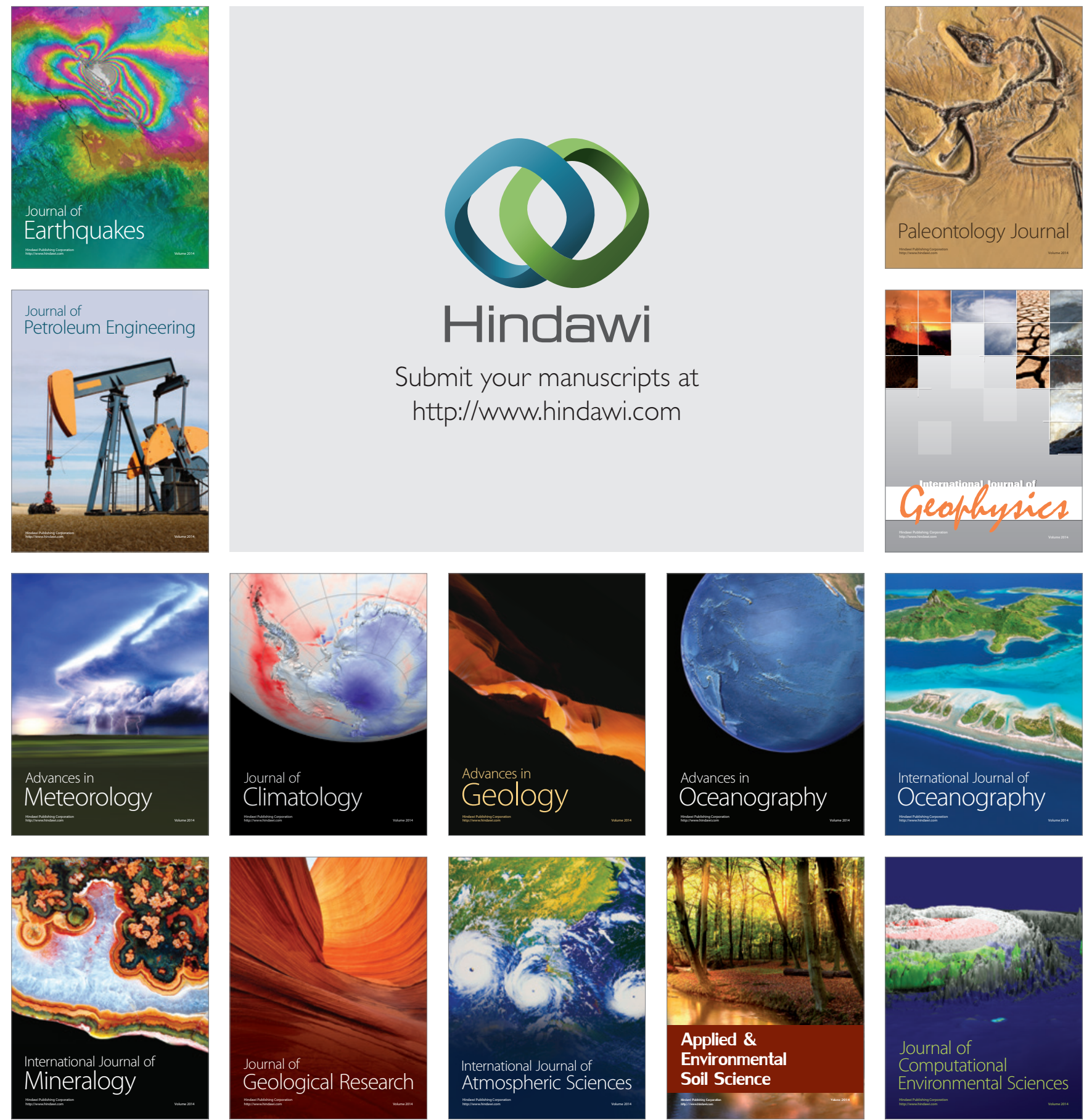